\title{
Geneza i znaczenie Inicjatywy Trójmorza jako narzędzia realizacji polskiego interesu narodowego oraz pogłębiania wspólpracy w obszarze Europy Środkowo-Wschodniej.
}

(wnioski uzyskane w ramach prac nad broszurą XXVII konferencji „Europa Karpat”, organizowanej przez Sejm RP w Karpaczu w dniach 8-9 września 2020 roku)

$\mathrm{P}$ ierwsze próby jednoczenia przez Polskę regionu Europy Środkowo-Wschodniej nie tylko na linii Zachód-Wschód, ale również na linii Północ-Południe pojawiły się już w okresie unii polsko-litewskiej i funkcjonowania bloku państw jagiellońskich. Rosnąca w kolejnych stuleciach mocarstwowa pozycja Polski i Litwy, a następnie Rzeczpospolitej Obojga Narodów stała się inspiracją dla kolejnych twórców polskiej myśli politycznej, która najpełniejszy wymiar osiągnęła w XX wieku u progu odzyskania przez Polskę niepodległości w 1918 roku. Stworzona wówczas przez Józefa Piłsudskiego koncepcja Międzymorza, miała umożliwić federalizację krajów i narodów położonych pomiędzy Niemcami i Rosją, aby stworzyć dla nich konkurencyjną przeciwwagę.

Chociaż koncepcje ścisłej współpracy w regionie Europy Środkowo-Wschodniej stanowiły trwały nurt polskiej myśli geopolitycznej, podkreślić należy, że realizowana obecnie inicjatywa Trójmorza nie jest kontynuacją projektów z przeszłości a stanowi formułę odpowiadającą na aktualne wyzwania w regionie. Najściślejsza grupa państw przynależących do inicjatywy Trójmorza to członkowie Grupy Wyszehradzkiej - Czechy, Polska, Słowacja i Węgry, które na początku lat 90. skoordynowały swoje działania na rzecz przystąpienia do NATO. Proces transformacji ustrojowej, a także integracja z politycznymi i gospodarczymi strukturami zachodu okazały się wspólnymi celami nie tylko dla wspomnianych państw, ale także dla innych graczy z regionu Europy Środkowo-Wschodniej. Większość państw Trójmorza dołączyła do NATO w 1999 lub w 2004 roku (z wyjątkiem Austrii niebędącej członkiem struktury i Chorwacji, która dołączyła do NATO w 2009 r.). Podobną drogę region Europy Środkowo-Wschodniej przebył w relacjach z Unią Europejską - wszystkie państwa Trójmorza dołączyły do tej struktury na przestrzeni 1995-2013 roku jednak pomimo szeregu reform 
wewnętrznych nowi członkowie UE wciąż zmagali się z dysproporcjami rozwojowymi, które poważnie osłabiały ich możliwości równoprawnej współpracy z najważniejszymi unijnymi graczami.

Balast polityczny, ekonomiczny i społeczny, wynikający z narzuconego po II wojnie światowej systemu komunistycznego, bardzo poważnie obciążał państwa EŚiW, sytuując je daleko w tyle za pozostałą częścią świata zachodniego pod względem poziomu życia obywateli czy też stopnia rozwoju gospodarczego i infrastrukturalnego. Sytuacja ta sprawiła, że w dyskursie publicznym zaczęto coraz częściej odwoływać się do podziału Unii Europejskiej na w pełni europejskie centrum i wymagającej europeizacji peryferie czy stosować pojęcie Europy Zachodniej w opozycji do jej pozostałych części.

W konsekwencji doszło do wyłonienia się spośród państw członkowskich UE, grupy państw Europy Środkowo-Wschodniej, które łączyło już nie tylko położenie geopolityczne i historyczne doświadczenia, ale także wspólne problemy gospodarcze i społeczne oraz agenda polityczna. Potrzeba zorganizowania przestrzeni geopolitycznej w Europie ŚrodkowoWschodniej, hasła prawa do bytu małych i średnich narodów czy przezwyciężanie decyzyjnej dominacji państw silniejszych pojawiły się w myślach politycznych wielu państw regionu i stały się dobrą płaszczyzną do zacieśniania więzi wielostronnych. Na obszarze Europy Środkowo-Wschodniej powołano nowe formaty współpracy - Trójkąt Sławkowski (styczeń 2015) i Bukaresztańska Dziewiątka (listopad 2015). Aktywność zwiększyła również Grupa Wyszehradzka, która stała się narzędziem realizowania wspólnych interesów regionu na forum Unii Europejskiej. Grunt pod budowanie współpracy regionalnej stwarzały ponadto wydarzenia na arenie międzynarodowej - nasilająca się rywalizacja USA-Rosja czy też zacieśnianie współpracy niemiecko-rosyjskiej w zakresie energetyki.

\section{Istota Inicjatywy Trójmorza (3SI)}

Wszystkie wymienione powyżej kwestie legły u podstaw powołania inicjatywy Trójmorza jako reakcji na aktualne problemy państw regionu oraz próby wzmocnienia ich międzynarodowej pozycji na forum Unii Europejskiej. Wymiar ten jest szczególnie podkreślany przez autorów projektu. Trójmorze w swojej istocie nie stanowi bowiem alternatywy dla współpracy $\mathrm{w}$ ramach Unii Europejskiej, a formę wzmocnienia i skoordynowania działań jej wschodnich członków. Został więc powołany w ścisłym związku z ideą integracji europejskiej.

Inicjatorami zawiązania współpracy w ramach Inicjatywy Trójmorza byli przywódcy Polski i Chorwacji: prezydent Andrzej Duda oraz prezydent Kolinda Grabar-Kitarović. 
Pierwsze rozmowy o projekcie zostały przez nich podjęte podczas pobytu prezydent Chorwacji w Krakowie a następnie kontynuowane przy okazji 70. Sesji ZO ONZ w Nowym Jorku. Formalnie format współpracy został zainaugurowany podczas Forum Strengthening Europe: Connecting North and South, które odbywało się w ramach I Szczytu Inicjatywy Trójmorza w Dubrowniku w dniach 25-26 sierpnia 2016 roku.

Inicjatywa przedstawiana jest jako próba organizowania przestrzeni w Europie Środkowo-Wschodniej w formie luźnego związku państw, co jest przejawem nowatorskiego podejścia do współpracy regionalnej. $W$ ramach Trójmorza nie dąży się bowiem do tworzenia sformalizowanych struktur organizacyjnych czy też mechanizmów współpracy równoległych do już istniejących. Akcentuje się natomiast pragmatyczny wymiar współpracy oparty na realizacji wymiernych projektów transgranicznych i makroregionalnych w jasno sprecyzowanych obszarach. Wspólna deklaracja w sprawie Inicjatywy Trójmorza przyjęta na Szczycie w Dubrowniku 25 sierpnia 2016 roku wskazuje enumeratywnie sektory współpracy o strategicznym znaczeniu dla państw zaangażowanych winicjatywę, do których należą: energia, transport oraz komunikacja cyfrowa.

Aby zapewnić dobrą realizację celów zdefiniowanych dla wymienionych wyżej obszarów, w ramach Inicjatywy Trójmorza powołano szereg instrumentów oraz platform współpracy. Należą do nich m.in. odbywające się corocznie Szczyty Inicjatywy Trójmorza a także spotkania w postaci Forum Biznesu 3SI. Dodatkowym wsparciem realizowanych inicjatyw jest Fundusz Inwestycyjny 3SI utworzony 29 maja 2019 roku w Luksemburgu. O podjęciu pierwszych projektów finansowanych $\mathrm{z}$ tego źródła rozmawiano na ostatnim Szczycie Trójmorza w Tallinie 19 października 2020 r.

\section{Stosunek społeczności międzynarodowej do Inicjatywy Trójmorza}

Warto zwrócić uwagę, że Inicjatywa Trójmorza zyskała duże zainteresowanie ze strony państw regionu, które traktowały ją jako sposób na zwiększenie swojego oddziaływania międzynarodowego. Spośród dwunastu państw uczestniczących w inaugurującym ją szczycie, sześć było reprezentowanych w randze głów państw (Bułgaria, Chorwacja, Litwa, Polska, Słowenia, Węgry) a sześć na szczeblu ministrów lub wiceministrów (Austria, Czechy, Estonia, Łotwa, Rumunia, Słowacja). Znaczenie spotkania podnosiła ponadto obecność światowych potęg takich jak USA, Chiny czy Turcja, które nie przynależą do formatu, ale z uwagą obserwują rozwój tego kierunku współpracy, co było widoczne także w ciągu kolejnych lat od inaugurującego spotkania w Dubrowniku. 
II Szczyt 3SI, który odbywał się w Warszawie w 2017 r. gościł delegację amerykańską z prezydentem USA Donaldem Trumpem. Z kolei 11 grudnia 2019 r. rząd USA zatwierdził 300 mln dolarów na Fundusz Trójmorza w ramach wsparcia inwestycji wzmacniających bezpieczeństwo energetyczne w Europie Wschodniej.

Zainteresowanie Inicjatywą Trójmorza rozwijało się również w Unii Europejskiej, której z jednej strony zależało na powiązaniu formatu z europejskimi celami, a z drugiej na aktywnym włączeniu się $\mathrm{w}$ projekty integracyjne rozwijane przez jej poszczególnych członków. W ten sposób do grona podmiotów wspierających 3SI dołączyła Komisja Europejska jak również wiodące instytucje finansowe w postaci Europejskiego Banku Inwestycyjnego oraz Europejskiego Banku Odbudowy i Rozwoju.

\section{Znaczenie Inicjatywy Trójmorza w wymiarze wewnętrznym i zewnętrznym.}

Korzyści płynące z rozwijanej inicjatywy Trójmorza dla polskiego interesu narodowego można oceniać zarówno z perspektywy wewnętrznej jak i zewnętrznej. Nie ulega wątpliwości, że projekt 3SI został stworzony aby zwiększać siłę oddziaływania państw Europy Środkowej i Wschodniej na międzynarodową politykę. W połączeniu więc $z$ innymi inicjatywami, takimi jak Trójkąt Weimarski czy Grupa Wyszehradzka wyposaża on Polskę nie tylko w kolejny instrument, którym może podkreślać swoje znaczenie jako aktora regionalnego, ale również, w instrument, który może wykorzystywać do kreowania wizerunku lidera projektów o charakterze integracyjnym. Ponadto stwarza on platformę do wypracowywania wspólnego kierunku działań zewnętrznych, przez co wyposaża zaangażowane w projekt państwa w możliwość skuteczniejszego kształtowania polityki na rzecz rozwoju Europy ŚrodkowoWschodniej np. na forum unijnym.

Współpraca w ramach Trójmorza niesie ze sobą korzyści także z perspektywy wymiaru wewnętrznego. Przez terytorium Polski biegną główne trasy, łączące państwa bałtyckie z resztą Wspólnoty: Via Baltica i Via Carpatia, które bardzo ściśle wpisują się w cele Inicjatywy Trójmorza. Ich rozwój i modernizacja, ma w założeniu przynieść wzrost konkurencyjności całego obszaru Europy Środkowo-Wschodniej oraz jego atrakcyjności dla zagranicznych inwestorów, na czym polska gospodarka $\mathrm{z}$ pewnością mogłaby skorzystać. Projekty realizowane w ramach 3SI to również inicjatywy na rzecz rozbudowy i modernizacji połączeń energetycznych, w celu przeorientowania istniejącego modelu dostaw i handlu energią w regionie Europy Środkowo-Wschodniej, co pozwala na zwiększenie dywersyfikacji źródeł surowców i poprawę bezpieczeństwa energetycznego zgodnie $\mathrm{z}$ polityką unijną. $\mathrm{Z}$ kolei 
współpraca w zakresie komunikacji cyfrowej stwarza możliwość czerpania korzyści $\mathrm{z}$ technologii $5 \mathrm{G}$ i jednolitego rynku cyfrowego.

W tym kontekście Inicjatywa Trójmorza wydaje się cennym instrumentem realizacji polskiej racji stanu, który uwzględnia zarówno ekonomiczny i modernizacyjny aspekt przekładający się na wewnętrzny stan państwa, jak również wymiar integracyjny i zjednoczeniowy, który możne znacząco wpływać na siłę oddziaływania Polski na arenie międzynarodowej.

\section{Bibliografia:}

1. Baziur, G., Trójmorze jako koncepcja bezpieczeństwa i rozwoju ekonomicznego Europy Wschodniej, Przegląd Geopolityczny, 23/2018.

2. Czyż A. Wspótpraca regionalna państw Grupy Wyszehradzkiej. Doświadczenia i perspektywy, Katowice 2018.

3. Orzelska-Stączek A., Kowal P., Inicjatywa Trójmorza: geneza, cele i funkcjonowanie, Warszawa 2019

4. Świder K. Europa Środkowa jako obszar projektowania geopolitycznego, Studia Europejskie, $2 / 2018$

5. Ukielski P., Inicjatywa Trójmorza $w$ polskiej polityce zagranicznej, Studia Europejskie, $2 / 2018$ 